\title{
Taste sensibility to phenylthiocarbamide and its relationship to food preferences
}

\section{Sensibilidade à feniltiocarbamida e sua relação com a preferência alimentar}

Marcela Maria Pandolfi ${ }^{1}$. Charles Yea Zen Chow ${ }^{2}$. Luciana Sayumi Fugimoto Higashi ${ }^{2}$. Ana Thamilla Fonseca $^{2}$. Myllena de Andrade Cunha ${ }^{2}$. Carolina Nunes França ${ }^{1,3}$. Patrícia Colombo-Souza ${ }^{1}$.

1 Post Graduation Program on Health Sciences, Santo Amaro University (UNISA). 2 Medicine Students, Santo Amaro University (UNISA). 3 Cardiology Division, Federal University of São Paulo (UNIFESP).

\section{ABSTRACT}

Introduction: Foods like cabbage, broccoli, pepper and wine, containing proteins such as phenylthiocarbamide (PTC), cause a bitter taste in some people. Studies showed the relation between tasting profile and the development of obesity, and consequently leading to cardiovascular disease. Objective: Compare the differences in the taste sensibility to PTC present in some foods in individuals classified according to the nutritional status. Methods: One hundred fifty-three patients classified as eutrophic, overweight or obese received one drop of each PTC solution in the tongue, since the most diluted to the individual perception to bitter taste, in a total of 15 increasing grades. Results: Participants were predominantly middle-aged females, eutrophics and supertasters. It was found a correlation between PTC solution and red wine in the three groups evaluated (eutrophic, obese and overweight). Besides, eutrophic and obese that disliked wine had more sensibility to PTC. Conclusion: Our main finding showed that eutrophic and obese that disliked red wine had more sensibility to PTC. We did not find differences in the sensitivity to PTC for the other foods analyzed (fried foods, fruit and vegetables).

Keywords: Taste sensibility. Pheniltiocarbamide. Red wine. Food preference.

\section{RESUMO}

Introdução: Alimentos como repolho, brócolis, pimenta e vinho contendo a proteína feniltiocarbamida (PTC), causam um gosto amargo para algumas pessoas. Estudos mostraram a relação entre diferenças de palatabilidade e o desenvolvimento da obesidade, consequentemente levando à doença cardiovascular. Objetivo: Comparar as diferenças de sensibilidade ao PTC presente em alguns alimentos em indivíduos classificados de acordo com o estado nutricional. Métodos: Cento e cinquenta e três pacientes classificados como eutróficos, sobrepeso ou obesos receberam uma gota de cada solução de PTC na língua, partindo da menor concentração até a percepção individual de gosto amargo. Resultados: Os participantes eram predominantemente mulheres de meia-idade, eutróficas e supersensíveis ao PTC. Foi encontrada uma correlação entre sensibilidade ao PTC e vinho tinto nos três grupos avaliados (eutróficos, sobrepeso e obesidade). Além disso, eutróficos e obesos que não gostavam de vinho tinham mais sensibilidade ao PTC. Conclusão: Nosso principal achado mostrou que eutróficos e obesos que não gostavam de vinho tinto tinham mais sensibilidade ao PTC. Não encontramos diferenças na sensibilidade ao PTC para os outros alimentos analisados (frituras, frutas e legumes).

Palavras-chave: Sensibilidade. Feniltiocarbamida. Vinho tinto. Preferência alimentar.

Corresponding Author: Patrícia Colombo-Souza, Santo Amaro University, Coordinator of the Post Graduate Program on Health Sciences. Professor Enéas de Siqueira Neto street, 340, Jardim das Imbuias, São Paulo. Zip code: 04829-030. Telephone: +55 11 2141-8810/ +55 11 21418584. E-mail: colombo@greco.com.br.

Conflict of interests: The authors have no conflicts of interest to declare.

Received: 20 Aug 2014; Revised: 03 Mar 2015; Accepted: 10 Apr 2015. 


\section{INTRODUCTION}

The development of research in genetics led to the discovery of factors that explain individual differences in the food preference for sweets or vegetables. ${ }^{1-4}$ The bitter taste found in some foods is recognized by the presence of chemical compounds such as phenol, polyphenol, ureas, thioureas, peptides and amino acids. $^{3,4}$

The variation in sensibility to bitter compounds of thioureas is a known genetic feature which can be a marker to differentiation of food habits. ${ }^{6,7}$ Foods containing proteins such as phenylthiocarbamide (PTC), which has a thiocyanate $(\mathrm{NC}=\mathrm{O})$ in the molecule structure, cause a bitter taste in some people. This compound is found in the Cruciferae or Brassicaceae vegetables such as broccoli, cabbage, cauliflower, watercress, spinach, bitter fruits and other foods such as pepper, green tea and red wine. ${ }^{5}$

The gene that determines the bitter taste of PTC is TAS2R38, which is located on the long arm of chromosome 7 (7q35q36) . ${ }^{8,9}$ The PTC presents five allelic forms and one of that (t) determines the insensitivity, being recessive in relation to the other alleles. ${ }^{10}$

Fox and colleagues (1932) found that people can be classified into two categories: those able to taste PTC, even at very low concentrations, referred as "tasters", and those who cannot taste the compound except at very high concentrations, the "nontasters". The "supertasters" were distinguished later by the heightened perception of the compound even in fatty foods. ${ }^{11}$

Some studies as described by Duffy et al (2007) showed that tasting profile might affect cardiovascular disease, since the food preferences can lead the individuals to a higher intake of unhealthy foods and, consequently, to the development of the factors associated, as hypertension, dyslipidemia and obesity. ${ }^{12}$

This work evaluated the relative sensitivity to phenylthiocarbamide (PTC) present in different foods of eutrophic, overweight and obese patients treated in the Hospital School Wladimir Arruda (HEWA) - Santo Amaro University, Sao Paulo - Brazil.

\section{MATERIAL AND METHODS}

\section{Study design and Inclusion/exclusion criteria}

Eutrophic, overweight and obese patients $(n=153)$ defined by the Body Mass Index (BMI) were included. The subjects (eutrophic, overweight and obese) were attended in the Hospital School Wladimir Arruda, Santo Amaro University (Brazil). As exclusion criteria: incorrect fill of the questionnaire and patients that did not agree to participate. The subjects were divided in three groups: non + weak tasters, medium tasters and super tasters.

\section{Data collection instrument}

A questionnaire with multiple-choice questions regarding food preferences was used to evaluate the subjects, before the management of taste solutions.

\section{Preparation of taste solutions}

The PTC plant extract was diluted in successive solutions comprising a total of 15 grades (from $7.9 \times 10^{-5}$ to $1.3 \mathrm{~g} / \mathrm{L}$ $\mathrm{g} / \mathrm{L}$ ), according to the protocol developed by Fox and colleagues in 1932. ${ }^{13}$ The solutions were prepared from reagent grade chemicals using boiled water after cooled. All fluids were stored at $4{ }^{\circ} \mathrm{C}$ and kept in room temperature before use.

\section{Determination of taste detection threshold}

Researchers dripped one drop of each PTC solution in the tongue of the patients, starting with the most diluted $(7.9 \mathrm{x}$ $10^{-5} \mathrm{~g} / \mathrm{L}$ ), following up to the individual perception to bitter taste.

\section{Ethics}

This study was approved by Ethical Committee from Santo Amaro University (number 185/10), according to the criteria established by Helsinki Declaration, with its modifications.

\section{Statistical Analysis}

Continuous variables are presented as means and standard error of the means (SEM) or medians and interquartiles (IQ). Parametric or non-parametric tests were used, as appropriate. A $p$ value of less than 0.05 was considered significant. All analyses were made using SPSS version 18.0 software.

\section{RESULTS}

\section{Study population}

Major characteristics of study subjects are shown in Table 1. Participants were predominantly middle-aged females and eutrophics.

Table 2 summarizes subjects' PTC taste data in relation to their gender. The majority of the participants were classified as female supertasters $(n=41 ; 27 \%$ of the total).

\section{Food preferences}

Figures 1 and 2 show the preferences for some foods analyzed (like - L or dislike - D, respectively), in the three groups evaluated (no- + weak tasters, medium tasters and super tasters). The preferences were: No- + weak tasters $=$ cabbage $(n=41)$, medium tasters $=$ cauliflower and broccoli $(n=51)$, super tasters $=$ white cheese $(n=49)$, without differences between groups. The foods that participants disliked were, in the majority: No- + weak tasters = turnip $(\mathrm{n}=30)$, medium tasters $=$ beer $(\mathrm{n}=36)$, super tasters $=$ radish $(n=40)$. Super tasters showed a high rejection for radish, compared with no- + weak tasters and medium tasters $(\mathrm{p}=$ 0.027). 
Table 1. Baseline demographic characteristics and body mass index for the groups eutrophic, obese and overweight.

\begin{tabular}{|c|c|c|c|}
\hline Characteristic & $\begin{array}{l}\text { Eutrophic } \\
\mathrm{n}=\mathbf{1 0 0}\end{array}$ & $\begin{array}{l}\text { Obese } \\
\mathbf{n}=\mathbf{2 8}\end{array}$ & $\begin{array}{l}\text { Overweight } \\
n=25\end{array}$ \\
\hline
\end{tabular}

\begin{tabular}{|c|c|c|c|c|}
\hline Age, years, median (IQR) & $35(27-49)$ & $41(37-46)$ & $38(32-47)$ & NS \\
\hline Male gender, n (\%) & $29(29)$ & $4(14)$ & $10(40)$ & NS \\
\hline Body weight, Kg, mean (SD) & $58,59(8,03)$ & $98,51(16,08)$ & $70(5,24)$ & $<0.0001$ \\
\hline Body mass index, $\mathrm{kg} / \mathrm{m}^{2}$, median (SD) & $22,35(1,65)$ & $37,09(5,04)$ & $27,17(1,58)$ & $<0.0001$ \\
\hline
\end{tabular}

Categorical variables expressed as n (\%); numerical variables presented as mean (SD) or median (IQR), as appropriate. ANOVA t test.

Table 2. Subjects' PTC taste ability categorized by taste degree and gender.

\begin{tabular}{llll}
\hline \hline PTC taste category & Male* & Female\# & Male + Female§ \\
& Total (n) & Total (n) & Total (n) \\
\hline \hline Non- + weak tasters (0-5) & 11 & 32 & 43 \\
Medium tasters (6-10) & 18 & 37 & 55 \\
Super tasters (11-15) & 14 & 41 & 55 \\
p between groups & NS & NS & NS \\
\hline \hline
\end{tabular}

$\overline{\bar{*}} \mathrm{n}=43 ;{ }^{\#} \mathrm{n}=110 ;{ }^{{ }} \mathrm{n}=153$. PTC $=$ phenylthiocarbamide.

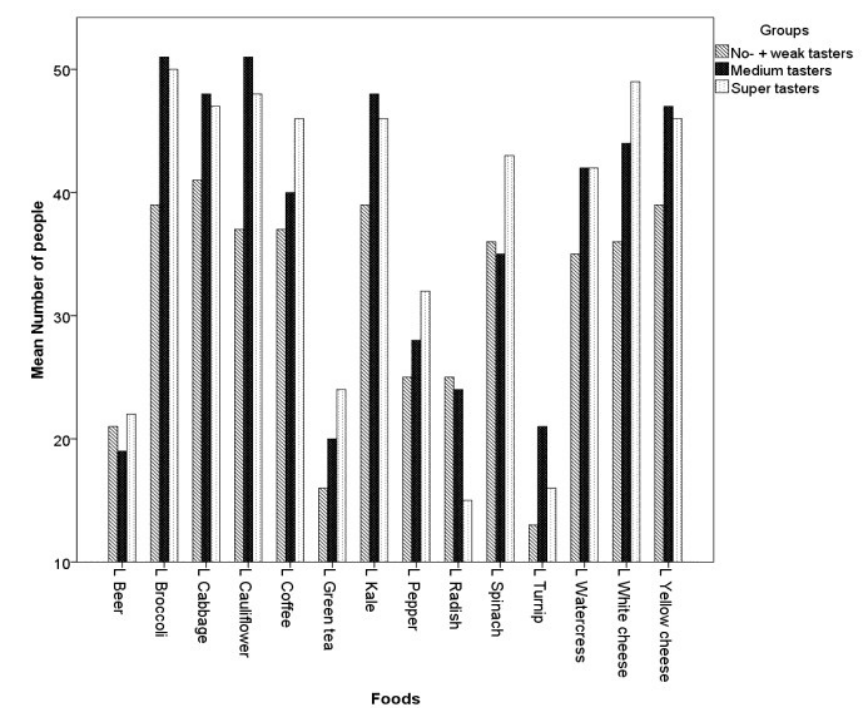

Figure 1. Mean ( \pm MSE) of food preferences in the three groups (no- + weak tasters, medium tasters and super tasters). Statistical comparisons are between the groups, without significant differences (Chi-square test).

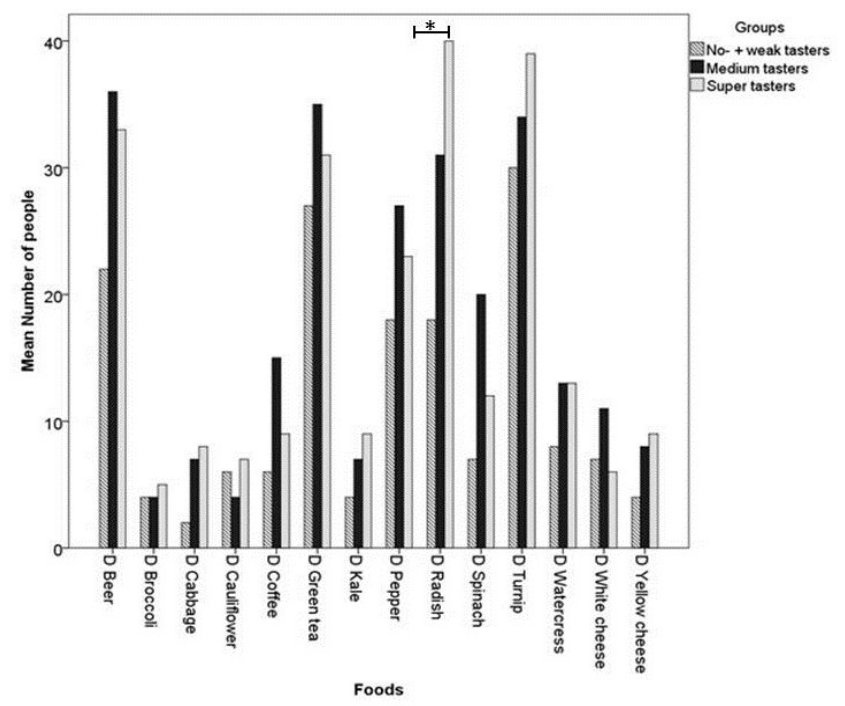

Figure 2. Mean ( \pm MSE) of foods that the subjects disliked in the three groups (no- + weak tasters, medium tasters and super tasters). Statistical comparisons are between the groups, (Chi-square test), * super tasters had a high rejection for radish, compared with no- + weak tasters and medium tasters $(\mathrm{p}=0.027)$. 
When foods were classified in groups (fried foods, fruit and vegetables, pastas or sweets - Figures 3 and 4), the preferences were fruits and vegetables in the three groups (No- + weak tasters: $n=28$, medium tasters: $n=31$, super tasters: $n=30$ ), without differences between groups. The food that participants disliked in the majority were fried foods in the three groups (No- + weak tasters: $n=31$; medium tasters: $\mathrm{n}=37$; super tasters: $\mathrm{n}=39$ ), with no differences between groups.

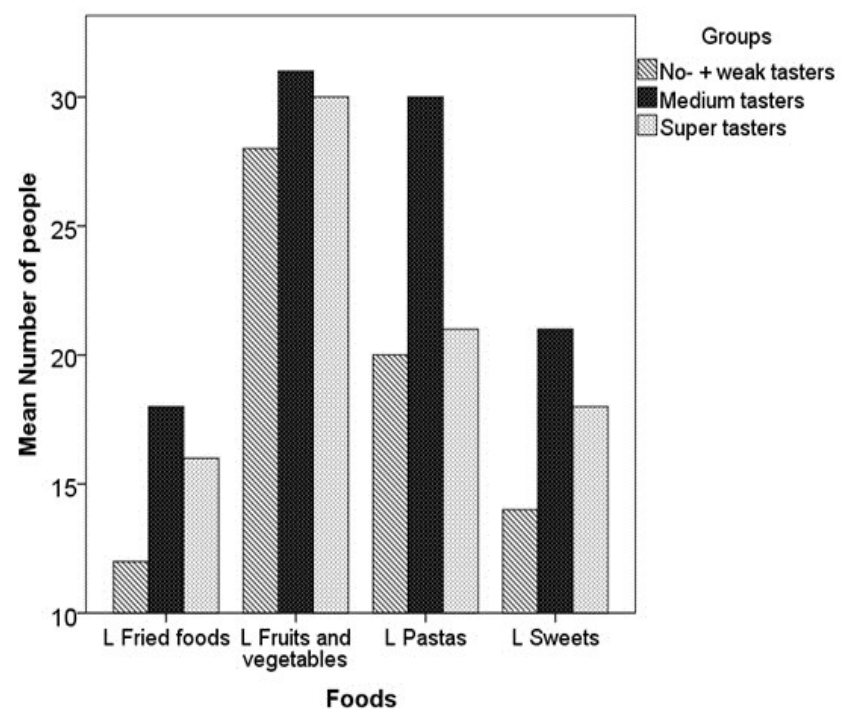

Figure 3. Mean ( \pm MSE) of food preferences, classified by groups (fried foods; fruits and vegetables; pastas and sweets). Statistical comparisons are between the groups, without significant differences (Chi-square test).

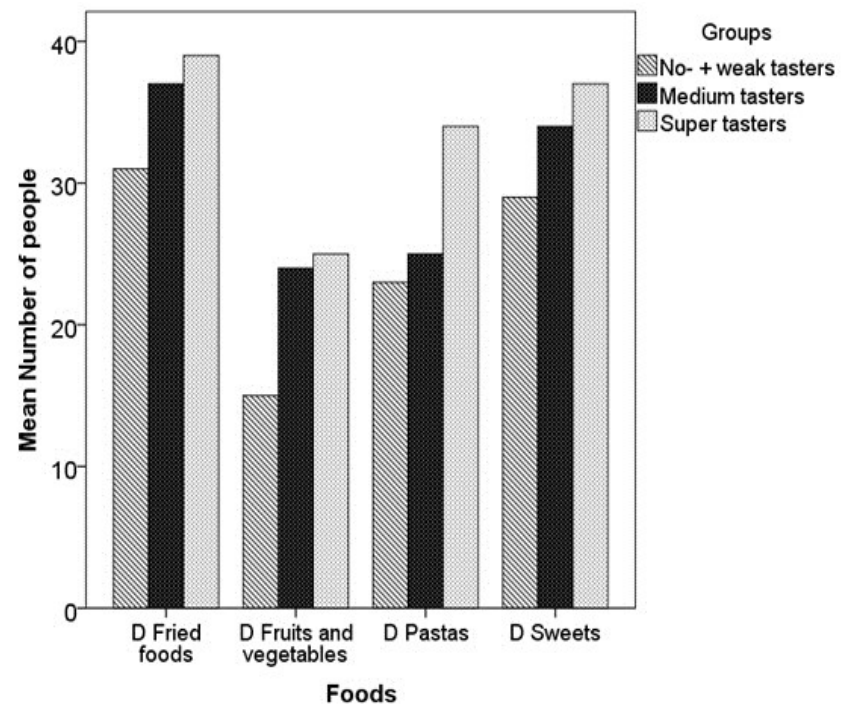

Figure 4. Mean ( \pm MSE) of foods that the subjects disliked, classified by groups (fried foods; fruits and vegetables; pastas and sweets). Statistical comparisons are between the groups, without significant differences (Chi-square test).

\section{Relation between red wine and PTC sensibility}

In order to examine the relationship of PTC sensibility and the foods evaluated, a Spearman correlation was run in three different groups (eutrophic, obese and overweight). It was found a correlation between PTC sensibility and red wine in the three groups evaluated (eutrophic: $r h o=0.203, p=0.044$; obese: $r h o=0.48, p=0.008$; overweight: $r h o=0.096, p=$ 0.008). Besides, eutrophic and obese that disliked red wine had more sensibility to PTC ( $p=0.045$ and $p=0.039$, respectively, Chi Square test).

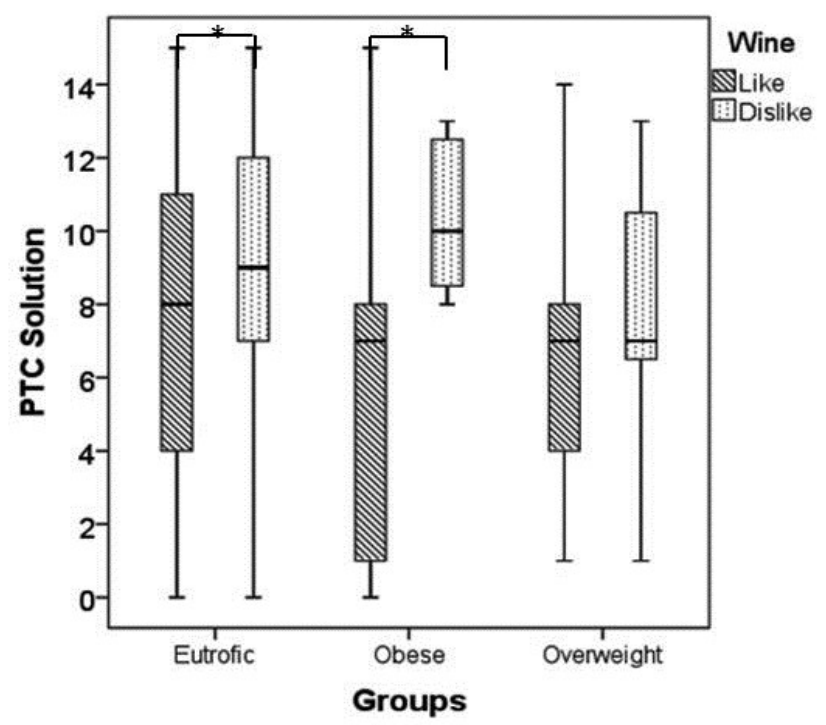

Figure 5. Relation of phenylthiocarbamide (PTC) solution and red wine.* Eutrophic and obese that disliked red wine had more sensibility to PTC $(p=0.045$ and $p=0.039$, respectively, Chi-Square test).

\section{DISCUSSION}

The variation in PTC perception may reflect the preference and choice of bitter foods, sweets, and fatty foods, which may be related to the risk of chronic diseases and, ultimately, influences on body weight, especially in current populations that acquired unhealthy eating habits adapted to the rhythm of life in the big cities. ${ }^{13}$

Some studies have shown protective dietary against metabolic syndrome, as Mediterranean model diet, and different tasting profiles might be related to the higher adherence to these diets. ${ }^{14}$

The studies evaluating the relation between PTC taste and obesity are still controversial; some searches found that nontasters have a higher BMI and greater risk of cardiovascular disease due to higher weight and greater intake of foods that are high in fat and sugar. ${ }^{15}$ On the other hand, there are studies showing no differences in the BMI between super tasters and no-tasters. ${ }^{13,16} \mathrm{We}$ also found no differences between BMI in the three groups evaluated (no+ weak tasters, medium tasters and super tasters).

Gender differences concerning taste sensibility to PTC have been reported by many authors. One study developed by Keller et al (2010) showed that nontaster male children are at higher risk to develop obesity than female. ${ }^{17}$ These differences, however, were not seen in some studies, as reported by Chang et al (2006); the authors claimed that it should be the results of age and individual characteristics of the subjects. ${ }^{18}$ 
The cut-off value to discriminate tasters and non-tasters is another factor that becomes difficult the comparison between the studies; furthermore, ethnic variability and demographic factors promote a high diversity in the classification of individuals as tasters and non-tasters in the different countries. $^{10,18}$

Many studies identifying food preferences have generally shown that the PTC chemical relative, 6-n-propylthiouracil (PROP) tasters, show greater dislike of some bitter vegetables and strong-tasting fruits. Differences in preferences for broccoli, cabbage, brussels sprouts, kale, asparagus, and spinach, have been seen. ${ }^{19-22}$ However, findings are conflicting in the majority of the studies. Two reports found no relation between PROP status and liking for broccoli, ${ }^{23,24}$ although one of these studies found a relationship between PROP status and preference for spinach. ${ }^{24}$

As shown in our study, there was a high degree of liking for vegetables (mainly cabbage, cauliflower and broccoli). However, liking for these foods did not vary between PTC taster groups, suggesting that the influence of PTC status on vegetable liking may be weak or absent. Similar results were found by TEPPER and colleagues (2009) with the similar compound PROP. ${ }^{3}$

Different results were seen for the degree of liking for spicy foods (pepper) and alcoholic beverages (beer). We found that the three groups expressed lower liking for these foods. Besides, super tasters had a high rejection for radish, compared with no- + weak tasters and medium tasters, suggesting that PTC status plays a role in the acceptance of some strong-tasting foods.

Another interesting finding was the relation between PTC solution and red wine, found when the population was classified as eutrophic, obese and overweight. Furthermore, eutrophic ad obese that disliked red wine expressed more sensibility to PTC. Hayes and Pickering (2012) evaluated the

\section{REFERENCES}

1. Blaskeslee AF. Genetics of sensory thresholds: taste for phenyl thio carbamide. Proc Natl Acad Sci U S A. 1932;18(1):120-30.

2. Snyder LH. Inherited taste deficiency. Science. 1931;74(1910):151-2.

3. Tepper BJ, White EA, Koelliker Y, Lanzara C, d'Adamo P, Gasparini P. Genetic variation in taste sensitivity to 6-npropylthiouracil and Its relationship to taste perception and food selection. Ann N Y Acad Sci. 2009;1170:126-39.

4. Tepper BJ, Williams TZ, Burgess JR, Antalis CJ, Mattes RD. Genetic variation in bitter taste and plasma markers of anti-oxidant status in college women. Int J Food Sci Nutr. 2009;60 Suppl 2:3545 .

5. Drewnowski A, Henderson SA, Barratt-Fornell A. Genetic taste markers and food preferences. Drug Metab Dispos. 2001;29(4 Pt 2):535-8. relationships between food and beverage adventurousness and taste phenotype (PROP bitterness) among wine drinkers that involved both regular consumers as wine experts. The authors found that wine experts expressed greater PROP bitterness than wine consumers, and the distribution of bitterness showed that experts were overrepresented among medium and super-tasters, and underrepresented among nontasters. $^{25}$

The research in this area, therefore, is non-conclusive and the contradictory results indicate that it is necessary additional studies to strengthen the significance of PTC sensibility as an indicator of metabolic disorders, as obesity. Besides, the relation between PTC taste and additional variables (as differences related to ethnicity and cultural identity) might be good options to better explore this theme.

\section{CONCLUSIONS}

Our main finding showed that eutrophic and obese that disliked red wine had more sensibility to PTC. We did not find differences in the sensitivity to PTC for the other foods analyzed (fried foods, fruit and vegetables). Taken together, these results contribute to better understand of the PTC sensitivity in different foods, in the individuals classified according to the nutritional status.

\section{Acknowledgments}

Hospital School Wladimir Arruda (HEWA), Santo Amaro University (Brazil).

\section{Declaration of interest statement}

There is not conflict of interest.

\section{Sources of funding}

This research received no specific grant from any funding agency in the public, commercial or not-for-profit sector.

6. Bartoshuk LM, Duffy VB, Miller IJ. PTC/PROP tasting: anatomy, psychophysics, and sex effects. Physiol Behav. 1994;56(6):1165-71.

7. Sharma K, Kaur GK. PTC bitter taste genetic polymorphism, food choices, physical growth in body height and body fat related traits among adolescent girls from Kangra Valley, Himachal Pradesh (India). Ann Hum Biol. 2014;41(1):29-39.

8. Kim UK, Jorgenson E, Coon H, Leppert M, Risch N, Drayna D. Positional cloning of the human quantitative trait locus underlying taste sensitivity to phenylthiocarbamide. Science. 2003;299(5610):1221-5.

9. Wooding S, Kim UK, Bamshad MJ, Larsen J, Jorde LB, Drayna D. Natural selection and molecular evolution in PTC, a bitter-taste receptor gene. Am J Hum Genet. 2004;74(4):637-46.

10. Morais JR, Silva JR, Conte RM, Grinolia MN, Raso V. Relação 
da sensibilidade à feniltiocarbamida (PTC) e o estado nutricional dos pacientes atendidos em um centro de saúde de Brasília - DF. Revista Brasileira de Obesidade, Nutrição e Emagrecimento. 2007;1(1):72-9.

11. Hayes JE, Keast RS. Two decades of supertasting: where do we stand? Physiol Behav. 2011;104(5):1072-4.

12. Duffy VB. Variation in oral sensation: implications for diet and health. Curr Opin Gastroenterol. 2007;23(2):171-7.

13. Fox AL. The relationship between chemical constitution and taste. Proc Natl Acad Sci U S A. 1932;18(1):115-20.

14. Jones JL, Comperatore M, Barona J, Calle MC, Andersen C, McIntosh M, et al. A Mediterranean-style, low-glycemic-load diet decreases atherogenic lipoproteins and reduces lipoprotein (a) and oxidized low-density lipoprotein in women with metabolic syndrome. Metabolism. 2012;61(3):366-72.

15. Drewnowski A, Henderson SA, Cockroft JE. Genetic sensitivity to 6-n-propylthiouracil has no influence on dietary patterns, body mass indexes, or plasma lipid profiles of women. J Am Diet Assoc. 2007;107(8):1340-8.

16. Duffy VB. Associations between oral sensation, dietary behaviors and risk of cardiovascular disease (CVD). Appetite. 2004;43(1):5-9.

17. Keller KL, Reid A, MacDougall MC, Cassano H, Song JL, Deng L, et al. Sex differences in the effects of inherited bitter thiourea sensitivity on body weight in 4-6-year-old children. Obesity (Silver Spring) 2010;18(6):1194-200.
18. Chang WI, Chung JW, Kim YK, Chung SC, Kho HS. The relationship between phenylthiocarbamide (PTC) and 6-npropylthiouracil (PROP) taster status and taste thresholds for sucrose and quinine. Arch Oral Biol. 2006;51(5):427-32.

19. Yackinous CA, Guinard JX. Relation between PROP (6-npropylthiouracil) taster status, taste anatomy and dietary intake measures for young men and women. Appetite. 2002;38(3):201-9.

20. Drewnowski A, Henderson SA, Levine A, Hann C. Taste and food preferences as predictors of dietary practices in young women. Public Health Nutr. 1999;2(4):513-9.

21. Keller KL, Steinmann L, Nurse RJ, Tepper BJ. Genetic taste sensitivity to 6-n-propylthiouracil influences food preference and reported intake in preschool children. Appetite 2002;38(1):3-12.

22. Bell KI, Tepper BJ. Short-term vegetable intake by young children classified by 6-n-propylthoiuracil bitter-taste phenotype. Am J Clin Nutr. 2006;84(1):245-51.

23. Dinehart ME, Hayes JE, Bartoshuk LM, Lanier SL, Duffy VB. Bitter taste markers explain variability in vegetable sweetness, bitterness, and intake. Physiol Behav. 2006;87(2):304-13.

24. Anliker JA, Bartoshuk L, Ferris AM, Hooks LD. Children's food preferences and genetic sensitivity to the bitter taste of 6-npropylthiouracil (PROP). Am J Clin Nutr. 1991;54(2):316-20.

25. Hayes JE, Pickering GJ. Wine expertise predicts taste phenotype. Am J Enol Vitic. 2012;63(1):80-4

\section{Como citar:}

Pandolfi MM, Chow CY, Higashi LS, Fonseca AT, Cunha MA, França CN. Taste sensibility to phenylthiocarbamide and its relationship to food preferences. Rev Med UFC. 2015 jan-jun;55(1):7-12. 